\title{
AZ ADATVÉDELMI JOG ÉS A SZEMÉLYES ADATOK MÚLTJA, JELENE ÉS JÖVÖJE AZ UNIÓS SZABÁLYOZÁSBAN
}

\author{
Past, Present and Future of Data Protection Law and Personal \\ Data in EU Legislation
}

Labancz Andrea ${ }^{1}$

\begin{abstract}
Absztrakt: Az áruk, a szolgáltatások, a tôke és a személyek szabad áramlásán alapuló egységes piac az Európai Unió gazdaságának motorját jelenti. Az egységes piacban rejlő gazdasági erő a digitális alapokon nyugvó egységes piac koncepciójának kidolgozásával újabb dimenzióba emelkedhet. A digitális gazdaság hajtóerejét az adatok jelentik, így az Európai Unió digitális egységes piacának zavartalan múködését biztosító komplex szabályegyüttes nélkülözhetetlen területét - quasi nulladik lépcsőfokát - az adatok szabad áramlására vonatkozó szabályok megalkotása biztosíthatja. Ezzel összefüggésben, az adatközpontú gazdaság realizálását a 2018-ban hatályba lépett általános adatvédelmi rendelet (GDPR) segíti, a személyes adatokra vonatkozó szabályozáson keresztül. 2020 májusában az uniós digitális gazdaság szabályozásának alapdokumentuma, a digitális egységes piaci stratégia az ötödik évfordulójához, a személyes adatok védelmét és a digitális gazdaság tényleges megvalósulását biztosító általános adatvédelmi rendelet pedig a második évfordulójához érkezik. Ezen események fényében a tanulmány az uniós adatvédelmi szabályozás és a személyes adatok helyzetének múltját, jelenét és lehetséges jövőképét tekinti át.
\end{abstract}

Kulcsszavak: adatvédelmi jog, GDPR, profilalkotás, személyes adat

\footnotetext{
${ }^{1}$ Szegedi Tudományegyetem, Állam- és Jogtudományi Kar, Üzleti Jogi Intézet, tanársegéd és Szegedi Tudományegyetem Állam- és Jogtudományi Doktori Iskola, PhD hallgató. Email címe: labancz@juris.u-szeged.hu

ORCID: https://orcid.org/0000-0001-8445-4082

A szerző további munkásságát lásd a Magyar Tudományos Művek Tára oldalán: https: $/ / \mathrm{m} 2 . \mathrm{mtmt}$.hu $/$ gui $2 /$ ?type $=$ authors\&mode=browse\&sel $=10060807$

2 A tanulmány az Innovációs és Technológiai Minisztérium ÚNKP-19-3-SZTE-57 kódszámú, Új Nemzeti Kiválóság Programjának szakmai támogatásával készült el.
} 
Abstract: The single market, based on the free movement of goods, services, capital and people, is thought to be the engine of the European Union's economy. However, the economic power of the single market may be taken to another dimension by developing the concept of the digital single market. Data is the driving force of the digital economy, so the creation of rules on the free flow of data can provide an indispensable area of a complex set of rules to ensure the proper functioning of the European Union's digital single market. In this context, the realization of the concept of a data-driven economy is facilitated by the General Data Protection Regulation (GDPR) through data protection law.

In May 2020, the Digital Single Market Strategy, the basic document for regulating the EU's digital economy, will celebrate its the fifth anniversary, and the General Data Protection Regulation, which ensures the protection of personal data and the realization of the digital economy, will arrive to its second anniversary. In the light of these developments, the study reviews the past, present and possible future of EU data protection regulation.

Keywords: data protection law, GDPR, profiling, personal data

\section{BEVEZETÉS}

A technológiai fejlődés modern életet alakító hatása megkérdőjelezhetetlen és arra az Európai Unió is pozitívan tekint: a digitalizációban rejlő előnyök kiaknázása az elmúlt évek egyik fő célkitűzésévé vált. A digitalizáció és a korunkat jellemző intenzív technológiai innováció kihasználása érdekében kidolgozásra került a digitális alapokon nyugvó uniós gazdaság koncepciója. ${ }^{3}$

A digitális gazdaság - és benne az adatgazdaság - kiépítésének meghatározó elemét jelenti az adatok szabad áramlásának biztosítása. ${ }^{4}$ Amennyiben azonban az adatok forrásaként szolgáló adatalanyok természetes személyek, a velük kapcsolatba hozható adatok személyes adatként is minősülnek. ${ }^{5}$

\footnotetext{
${ }^{3}$ BIZOTTSÁGI KÖZLEMÉNY, EURÓPAI DIGITÁLIS EGYSÉGES PIACI STRATÉGIA, 2015. 2-4.o.

4 COMMISSION STAFF WORKING DOCUMENT ON THE FREE FLOW OF DATA AND EMERGING ISSUES OF THE EUROPEAN DATA ECONOMY 2017. 4-10.o.

5 Helberger ET AL. 2017. 1430-1432.o.
} 
Éppen ezért, a digitális gazdaságban kiemelt jelentőséggel bír az adatvédelem ${ }^{6}$. Ezt a nézetet erősíti meg az Európai Tanács 2013. októberi következtetéseiben, amely szerint a digitális egységes piac megvalósulásának egyik nélkülözhetetlen eszköze a szilárd és általános adatvédelmi szabályozás. ${ }^{7}$ Válaszul az Európai Tanács következtetéseire, a 2014-es, „Úton a prosperáló adatközpontú gazdaság felé” c. bizottsági közlemény ugyancsak az adatvédelmi szabályok fontosságát hangsúlyozza, és kitér arra, hogy a digitális gazdaság és az adatforradalom meghatározó - de nem kizárólagos - elemét jelenti az emberi tevékenységekről való adatgyüjtés és adatfeldolgozás is. ${ }^{8}$

A személyes adatok ugyanakkor gazdasági értékkel is rendelkeznek. ${ }^{9}$ Ezt erôsíti meg az az elmélet is, amely szerint „,az adat az új olaj." "10

Fentiekkel összefüggésben, a kutatás azon a hipotézisen alapul, hogy az uniós adatvédelmi szabályozás akkor képes elegendő védelmet biztosítani a személyes adatok tekintetében, ha folyamatosan reagál a gazdasági környezetre.

A hipotézis igazolásához a tanulmány vizsgálja, hogy milyen lényegi változáson ment keresztül az uniós szabályozás az első generációs adatvédelmi szabályok megalkotásától kezdődően napjainkig. A kérdés megválaszolásához elengedhetetlen az európai uniós adatvédelmi szabályozás rövid történeti áttekintését elvégezni, amelyhez a történeti elemzés módszere szolgál segítségül. A hatályos adatvédelmi szabályok vizsgálata során a tanulmány a digitális egységes piac és az adatközpontú gazdaság koncepciójára is figyelemmel van. Ezek vizsgálata során a szakirodalmi áttekintés és a kritikai elemzés módszerét alkalmazza.

\section{AZ ADATVÉDELMI SZABÁLYOZÁS ÉS A SZEMÉLYES ADATOK MÚLTJA}

\footnotetext{
${ }^{6}$ A digitális gazdaság egyik fontos szegmense, az online kereskedelem kapcsán is számos is erőteljesen felmerül az adatvédelem, mint problémakör. Az online kereskedelem előnyeiről hátrányairól, valamint kockázatairól bővebben lásd SZŰCS, 2020.

7 EURÓPAi TANÁCS 2013. OKTÓBER 24-25. KÖVETKEZTETÉSEK, 2013. 4.o.

8 BIZOTTSÁGI KÖZLEMÉNY, ÚTON A PROSPERÁLÓ ADATKÖZPONTÚ GAZDASÁG FELÉ, 2014. 1.o.

${ }^{9}$ OECD, 2013. 10-18.o.

${ }^{10}$ GRAEF, 2015, 474.o.
} 


\subsection{EURÓPAI SZABÁLYOZÁS - AZ ADATVÉDELEM EGYES KORSZAKAI}

A magánszféra védelméhez szorosan kapcsolódó adatvédelem megszületését - a számítástechnika fejlődésére és a tömeges adattárolásra adott reakcióként - az ún. első generációs adatvédelmi szabályok megjelenéséhez szokás kötni. ${ }^{11} \mathrm{Az}$ adatvédelmi szabályozás középpontjában a személyes adat áll, vagyis az az adat, amely alkalmas az adatalany azonosítására. ${ }^{12}$ Maga az adatvédelem az egyén magánszférájának jogi védelmeként értelmezhető, amely az automatizált adatfeldolgozásból eredő veszélyekre alakult ki válaszul. ${ }^{13}$

Fontos hangsúlyozni, hogy az adatvédelmi jog fejlődése során az adatvédelmi szabályok célja és az adatalanyok jogai eltérô tartalommal bírtak az egyes korszakokban. ${ }^{14}$

Mayer-Schönberger szerint az első generációs adatvédelmi szabályokról az 1970-es évek elejétől lehet beszélni, és értelmezése szerint azokat sajátos technológiai szemlélet jellemzi. A szerző rámutat, hogy az évtized második fele szabályainak középpontjában kevésbé a technológia, sokkal inkább az egyén és annak jogai szerepelnek; ezekben látja a második generációs szabályokat. A harmadik generációs adatvédelmi szabályok megjelenését az 1983-as német alkotmánybírósági népszámlálás-ítélethez köti és azokat az információs önrendelkezési jog szemléletével összefüggőnek tekinti. A negyedik generáció szabályai esetében pedig már a szektorspecifikus adatvédelem is megjelenik. ${ }^{15}$

A magyar jogirodalomban Majtényi az adatvédelmi szabályozás három generációját különbözteti meg. Álláspontja szerint az egyes korszakok közös jellemzői a számítógépes rendszerek fejlődésében, a gazdasági környezet megváltozásában összegezhetőek. ${ }^{16}$ Jóri ugyancsak három korszakot lát megvalósulni az adatvédelmi szabályozásban. Elméletében az adatvédelem

\footnotetext{
11 Az európai adatvédelmi jog fejlődésének történetében a szabályozás több generációja különböztethető meg. Az adatvédelmi szabályok korszakok szerinti felosztása és értelmezése általánosan elfogadott; az egyes szerzők azonban eltérő állásponton vannak abban a tekintetben, hogy annak három vagy négy generációja adható meg. Vö. JóRI-Soós 2016. 20.o., 26.o.; SZŐKE, 2014. 24.o.

12 Helberger et AL. 2017. 1431.o.

13 JÓRI-SOÓS, 2016. 21.o.

14 A tanulmány nem az összes elméletet ismerteti. Vö. JÓRI-SOÓs, 28.o.

15 MAYER-SCHÖNBERGER, 1997. 221-236.o. Ehhez lásd még: JÓRI - SOÓS, 2016. 26.o.

16 MAJTÉNYI, 2003. 582-583.O.
} 
első korszaka az adatvédelmi szabályok megjelenésétôl az 1983-as német alkotmánybírósági határozatig terjedő időszakot öleli fel, a második korszak az információs önrendelkezési jog doktrínájának kidolgozásától a harmadik korszakig tart, a harmadik korszak kezdetének pedig a német Teledienstedatenschutzggesetr. 1997-es kidolgozását tekinti. ${ }^{17}$ Szőke rávilágít, hogy a fentiek mellett, Hegedûs munkájában fellelhető a negyedik generációs szabályozás gondolata is, amely az önszabályozáson, az internet-specifikus adatvédelmi kérdéseken és az egyes technológiák megjelenésén alapul. ${ }^{18}$

Az európai adatvédelmi jog fejlődésére vonatkozó egyes nézetek összegzéseként az a következtetés vonható le, hogy az adatvédelmi szabályozás a kezdetektől figyelemmel volt a gazdasági környezetre és az informatikai-technológiai vívmányokra. Amíg azonban az első generációs adatvédelmi törvények tárgya elsősorban a nagy adatbázisok transzparenciája volt és nem az adatalany személyes adatai feletti rendelkezési jog, addig a második generációs adatvédelmi szabályok már az adatkezelés teljes folyamatára biztosítottak meghatározott jogokat az adatalanyoknak ugyanakkor azok kevésbé voltak technológiafókuszúak. A harmadik generációs szabályozással azonban ismételten a technológiára reflektáló adatvédelmi szabályok jelentek meg. ${ }^{19}$

\subsection{EURÓPAI UNIÓS SZABÁLYOZÁS}

Az adatvédelmi szabályozás tekintetében nemcsak a nemzeti, hanem az egyes nemzetközi szervezetek adatvédelmi jogi aktusai is jelentősek. Ilyenek az OECD 1980-as iránymutatásai, illetve az első kötelező erejű nemzetközi adatvédelmi tárgyú okmány, az Európa Tanács 1981. évi 108. számú egyezménye. ${ }^{20}$

Az adatvédelemmel kapcsolatos közösségi jogalkotásban a Lisszaboni Szerződés tekinthető meghatározónak, amelynek hatályba lépésével egy egyértelmú adatvédelmi rendszer kialakítására került sor. ${ }^{21} \mathrm{~A}$ Lisszaboni

\footnotetext{
${ }^{17}$ SZŐKE, 2015. 24-25.o., Vö. JÓRI - SOÓs, 2016. 26-27.o.

18 SZŐKE, 2015. 24-25.o.

19 JÓRI-SOÓS, 2016. 25-48.o.

20 Európai Parlament, 2020. A SZEMÉlyes AdATOK VÉdELme 2.o.

21 A Lisszaboni szerződés hatálybalépése előtt az adatvédelemmel kapcsolatos szabályok a magán- és üzleti célokat szolgáló adatvédelem és a bűnüldözési célokat szolgáló adatvédelem - vagyis az első és a harmadik pillér - között oszlottak meg. Vö. BENDIK, 2018. 29-30.o.
} 
Szerződéssel elfogadott módosítások következménye, hogy az Európai Unió Alapjogi Chartája ugyanolyan jogi kötőerővel bír, mint az alapítószerződések, így önálló alapjogként biztosítja a személyes adatok védelméhez való jogot. Az uniós adatvédelmi szabályozás alapdokumentumává az Európai Unió működéséről szóló szerződés (EUMSZ) vált, amely 16. cikkének (1) bekezdése deklarálja a személyes adatok védelmét. ${ }^{22}$

Az uniós adatvédelmi szabályozás fontos dokumentuma az Európai Parlament és a Tanács 95/46/EK irányelve (adatvédelmi irányelv), amely megalkotásának indoka az informatikai fejlődés és az annak való megfelelés volt. ${ }^{23}$ Szükséges kiemelni, hogy az adatvédelmi irányelv hatálya nem terjedt ki az adminisztratív feladatokat ellátó intézményekre és szervezetekre annak címzettjei a tagállamok voltak. Ezt a hiányt részben kezelte az Amszterdami Szerződés, azonban a hatékony adatvédelmi jog biztosításához további szabályokra is szükség volt. ${ }^{24}$

Habár az adatvédelmi irányelvvel a személyes adatok tagállamok közötti szabad áramlása megvalósíthatóvá vált, a technológiai innováció fejlődése, valamint az egyes üzleti és gazdasági modellek megváltozása, a globalizáció térnyerése szükségessé tette az uniós adatvédelmi szabályok revízióját. Erre az Európai Bizottság által 2012-ben előterjesztett adatvédelmi reformot tartalmazó javaslatcsomaggal került sor. ${ }^{25}$

Annak ellenére, hogy nem kifejezetten adatvédelmi tárgyú, az uniós adatvédelmi szabályozás tekintetében mégis fontos mérföldkőnek tekinthető az egységes digitális piaci stratégia is, amelyet az Európai Unió - felismerve az infokommunikációs technológiákban rejlő lehetőségeket - 2015 májusában fogadott el. A stratégia az egységes uniós piac egy magasabb

\footnotetext{
22 BENDIK, 2018. 29.o.

${ }^{23}$ LUKÁCS, 2017. 126.o.; Szükséges megjegyezni, hogy az adatvédelmi irányelvvel felállításra került a 29. cikk szerinti Adatvédelmi Munkacsoport is, amely a magánélet és a személyes adatok védelmével kapcsolatos ügyekkel foglalkozott. Vö. ARTICLE 29 WORKING PARTY WORK Program, 2013. 1-3.o.

${ }^{24}$ Ezzel összefüggésben, az uniós adatvédelmi jog további fontos szabályait tartalmazta a 2000-ben elfogadott 45/2001/EK rendelet, amely a személyes adatok közösségi intézmények és szervek által történő feldolgozása tekintetében az egyének védelme, valamint az ilyen adatok szabad áramlása tekintetében állapított meg szabályokat; illetve az 1247/2002/EK határozat, amely az európai adatvédelmi biztos feladatainak ellátására vonatkozó szabályokról és általános feltételekről szólt (hatályon kívül helyezte a 2018/1725 rendelet), valamint a 2008/977/IB kerethatározat, amely a büntetőügyekben folytatott rendőrségi és igazságügyi együttműködés keretében feldolgozott személyes adatok védelméről szólt. Vö. BENDIK, 2018. 26-27.o.
}

${ }^{25}$ EU SZAKPOLITIKÁK ADATVÉDELMI REFORM, 2020. 
dimenziójának képét rajzolja ki, amelyben - hasonlóan az egységes piachoz - biztosított az áruk, a személyek, a szolgáltatások és a tőke szabad mozgása, ugyanakkor már kifejezetten használja az IKT szektor és a technológiai innováció előnyeit is. ${ }^{26}$

A digitális egységes piaci stratégia adatvédelmi jelentőségét az adja, hogy abban fontos szerep jut a személyes adatoknak is. A digitális gazdaság, az uniós adatáramlás kiépítését azonban hátráltatja a bizalom hiánya, vagyis az, ha az uniós fogyasztók és vállalkozások adatvédelemmel kapcsolatos aggályaik miatt nem vesznek részt az adattárolásban és feldolgozásban. ${ }^{27}$ Fentiek gyakorlati megvalósulását jogi eszközökkel alátámasztandó, az Európai Parlament és a Tanács 2016. április 27-én elfogadta az uniós adatvédelmi csomagot, amelynek egyik eleme a fenti célokat megvalósítani képes általános adatvédelmi rendelet, a GDPR volt. ${ }^{28}$

\section{AZ ADATVÉDELMI SZABÁLYOZÁS ÉS A SZEMÉLYES ADATOK JELENE, ÉS LEHETSÉGES JÖVŐKÉPE}

A fentiekben megfogalmazott hipotézissel összefüggésben, annak meghatározásához, hogy a GDPR elegendő védelmet biztosít-e a személyes adatoknak, a tanulmány egy tipikus problémát állít középpontba: a személyes adatok fizetőeszközkénti felhasználását, amelyre tipikusan az online platformok szolgáltatásai során kerül sor. ${ }^{29}$

Az online platformok többsége kétoldalú piacra épül, ami azt jelenti, hogy fogyasztói felhasználóiknak ún. zéró áras (ingyenes) szolgáltatást nyújtanak, tényleges bevételeik pedig az elektronikus hirdetési felületek

\footnotetext{
26 A stratégia három pilléren nyugszik: az internetes árukhoz való jobb hozzáférésen, a digitális hálózatokat és szolgáltatásokat támogató megfelelő infrastruktúra és szabályozás kialakításán és az európai digitális gazdasági növekedés maximalizálásán. Vö. BIZOTTSÁGI KÖZLEMÉNY, EURÓPAI DIGITÁLIS EGYSÉGES PIACI STRATÉGIA, 2015. 2-3.o., 9-17.o.

27 BizotTSÁGi KÖZLEMÉNY, EuRÓPAi DigITÁLIS EGYSÉGES PIACI STRATÉGIA, 2015. 1516.o.; Vö. COMMUNiCATION FROM THE COMMISSION ON BUILDING A EUROPEAN DATA ECONOMY, 2017. 5.

$28 \mathrm{Az}$ adatvédelmi reformcsomag másik eleme a bűnüldözési célból kezelt személyes adatok védelmére vonatkozó irányelv. Tekintettel azonban arra, hogy a tanulmány az adatközpontú gazdaság és személyes adatok védelmének témakörére fókuszál, részleteiben nem foglalkozik a bűnügyi irányelvvel. Vö. 2016/680/EU IRÁNYELV

${ }^{29}$ Helberger ET AL. 2017. 1428-1432.o.
} 
értékesítéséből származnak. ${ }^{30}$ Fontos azonban kiemelni, hogy az ilyen platformok szolgáltatásaikat azért tudják pénzbeli ellenszolgáltatás nélkül nyújtani fogyasztói felhasználóknak, mert ismerik azok személyes adatait. Azokból következtetést vonhatnak le a fogyasztó preferenciáira, vélhető jövőbeli ügyleti döntéseire és ezek ismeretében képesek a bevételi forrásukként szolgáló célzott viselkedésalapú reklámozásra. ${ }^{31}$ Ahogyan arra több szerző is rámutat, a fogyasztói felhasználó így lényegében a személyes adataival „fizet” a szolgáltatásért. ${ }^{32}$

Fentiekre tekintettel, a tanulmány a továbbiakban kifejezetten a GDPR és a digitális gazdaság metszetét vizsgálja, és a személyes adatok védelmének eszközeit mutatja be a digitális gazdaság tipikus szereplői, az online platformok adatkezelése során. ${ }^{33}$

Ehhez szükséges kiemelni, hogy a 2018. május 25-től alkalmazandó GDPR több változást is hozott az adatvédelmi szabályozás területén, amelyek a személyes adatok magas szintű védelmét hivatottak biztosítani. ${ }^{34}$

Az első ilyen jelentős változás az uniós jogi aktus természetében fedezhető fel: a korábbi irányelvi szabályozást a rendeleti szabályozás váltotta fel, amivel az adatáramlás egységes uniós szabályozása valósulhat meg. ${ }^{35}$

Hasonlóan az adatvédelmi irányelvhez, a GDPR személyi hatálya az élő, és azonosított vagy azonosítható természetes személyekre terjed ki, ${ }^{36}$ tárgyi hatálya pedig a személyes adatok minden olyan kezelésére, amely részben vagy egészben automatizált módon történik, valamint azoknak a személyes adatoknak a nem automatizált módon történő kezelésére, amelyek valamely nyilvántartási rendszer részét képezik, vagy amelyeket egy

30 European COMISSION, JRC TeChnical Report: THE ECONOMICS OF OWNership, ACCESS AND TRADE IN DIGITAL DATA. 2017. 40-41.o.; Vö. ARDOLINO ET AL. 2020. 3-5.o.; MARTENS, 2016. 13-14.o.

${ }^{31}$ Kerber, 2016. 7-8.o.; Furman JeLENTÉs, 2019. 21-24.o.; Vö. C-40/17. SZ. ÜGY 75.o.

32 Helberger et AL. 2017. 1428-1431.o.; Vö. Martens, 2016. 36-37.o.; Graef, 2015, 473-474.o.; BERGEMANN - BONATTI, 2015. 276-286.o.

33 A 2019/1150 online platform rendelet alapján online platformok alatt az online piactereket, az online szoftver alkalmazástékákat, az online közösségi médiát, és az online keresőprogramokat kell érteni. Vö. 2019/1150 RENDELET

34 A tanulmány a GDPR-nak kifejezetten azokat a rendelkezéseit emeli ki, amelyek az adatközpontú gazdaságban is jelentős szereppel bírnak. A teljesség igénye miatt, vö. EU COMMISSION, A NEW ERA FOR DATA PROTECTION IN THE EU, 2018. 1-3.o.

35 COMMISSION STAFF WORKING DOCUMENT ON THE FREE FLOW OF DATA AND EMERGING ISSUES OF THE EUROPEAN DATA ECONOMY, 2017. 20.o.

${ }^{36}$ ESZTERI, 2018. 51-53. o. 
nyilvántartási rendszer részévé kívánnak tenni. ${ }^{37}$ Eltérően azonban az adatvédelmi irányelvtől, a GDPR extraterritoriális hatályú, így szabályait attól függetlenül is alkalmazni kell, hogy az adatkezelés az Unió területén történik vagy sem. ${ }^{38}$ Emellett, az Unióban tevékenységi hellyel nem rendelkező adatkezelők vagy adatfeldolgozók esetében is a GDPR alkalmazandó akkor, ha az adatkezelő vagy adatfeldolgozó az Unióban tartózkodó adatalanyok számára nyújt árukat vagy szolgáltatásokat (akár ingyenesen is), illetve az unióban tartózkodó érintettek viselkedésének megfigyeléséhez kapcsoló tevékeny-séget végez. ${ }^{39}$ A GDPR hatálya így kiterjedhet a digitális gazdaság meghatározó szereplőire, az egyes online platformokra is. $^{40}$

A GDPR nem hozott lényegi változást a személyes adatok fogalma esetében, sokkal inkább összegző meghatározásra törekedett, és azok tág értelmezése előtt tette le a voksát. Összefoglalóan: bármely információt személyes adatnak tekint, amely kihat az egyén helyzetére. ${ }^{41}$ Ahogyan az már az adatvédelmi irányelv esetében is kirajzolódott, a személyes adatok körébe tartozhatnak az adatalany által átadott adatok, az adatalany megfigyelésével létrejövő adatok vagy az adatalannyal kapcsolatban az adatokból relatíve levonható következtetések, valamint a más forrásokból az érintettre levonható következtetések is. ${ }^{42}$

Változást jelent azonban, hogy expressis verbis a személyes adatok körébe rendeli a GDPR az egyes online azonosítókat. Az ilyen azonosítók

\footnotetext{
${ }^{37}$ Ugyancsak változatlan, hogy nem tartozik az uniós adatvédelmi szabályozás hatálya alá a magáncélú, a bűnüldözési célú és a nemzetbiztonsági adatkezelés. Vö. C-101/01. SZ. ÜGY 99.o.

38 EDPB GUIDELINES 3/2018 ON THE TERRITORIAL SCOPE OF THE GDPR (ARTICLE 3), 2019. 5-13.o.

39 Vö. EDPB GuIDELINES 3/2018 ON THE TERRITORIAL SCOPE OF THE GDPR (ARTICLE 3), 2019. 13-22.o.

40 Vö. EDPS RESPONSE ON THE REGULATORY ENVIRONMENT FOR PLATFORMS, ONLINE INTERMEDIARIES, DATA AND CLOUD COMPUTING AND THE COLLABORATIVE ECONOMY, 2015. 2-5.o.

41 OSZTOPÁNI - RÉvÉSZ, 2018. 64.o.

42 ARTICLE 29 WORKING PARTY OPINION 4/2007 ON THE CONCEPT OF PERSONAL DATA, 2007. 12-21.; Vö. TNS-NIPO, 2011. 5-6.; EUROPEAN COMISSION, JRC TECHNICAL REPORT: THE ECONOMICS OF OWNERSHIP, ACCESS AND TRADE IN DIGITAL DATA, 2017. 7.; ENISA, 2012. 7-8.o.
} 
az online platformok tevékenysége során alkalmazott profilalkotás és az automatikus döntéshozatal technikai eszközeként szolgálhatnak. ${ }^{43}$

Profilalkotás esetében egy természetes személy megfigyelésén keresztül történő automatizált adatgyüjtés és felhasználás (automatizált adatkezelés) történik, amellyel a természetes személy egyes jellemzőinek elemzése, értékelése, személyiségének mintegy megismerése, sőt, akár potenciális jövőbeli döntéseinek predesztinálása is megvalósulhat. A profilalkotáshoz kapcsolódó jellegzetesség, hogy egyes technológiák és online azonosítók alkalmazásával akár a természetes személyek teljes internetes tevékenysége megfigyelhető, arról adatok gyűjthetőek, a gyűjtött adatok pedig elemezhetőek, azokból következtetések vonhatóak le és később azok akár üzleti célokra is felhasználhatóak. ${ }^{44}$ A személyiségprofilok felállításának és alkalmazásának számos területe van, üzleti szempontból legnépszerúbbnek a viselkedésalapú reklámozás tekinthető. ${ }^{45} \mathrm{Ki}$ kell azonban emelni, hogy Helberger szerint a profilalkotás az egyének és a fogyasztói döntések manipulálására is használható. ${ }^{46}$

$\mathrm{Az}$ automatikus döntéshozatal a profilalkotással szoros kapcsolatban álló adatkezelési mûvelet, amely a személyes adatok kiértékelésének nem emberi, gépi tevékenységét jelenti. ${ }^{47} \mathrm{Az}$ automatikus döntéshozatal üzleti jelentőségét éppen az adja, hogy kizárólag technológiai eszközök alkalmazásával kerülhet sor döntések meghozatalára. Az automatikus döntéshozatallal kombinált profilalkotás a vállalkozások számára gazdasági előnnyel jár, a fogyasztók számára azonban hátrányokat is jelenthet. A személyiségprofilokban rejlő potenciális veszélyek már az első generációs adatvédelmi szabályozás kialakulásakor is felmerültek, jelen korunkban

43 Ilyen online azonosító lehet például az IP-azonosító vagy a cookie azonosító. HELBERGER ET AL. 2017. 13-15.o.; Vö. TNS-NIPO, 2011. 74-75.o.; C-582/14. SZ. ÜGY, 3939.o.; C-673/17. SZ. ÜGY, 76-81.o.

44 Vö. BERGEMANN - BONATTI, 2015. 269-261.o.

45 ARticle 29 Working PARTY, OPINION 2/2010 ON ONLINE BEHAVIOURAL ADVERTISING, 2010. 4-5.o.; Vö. EUROPEAN COMISSION, JRC TECHNICAL REPORT: THE ECONOMICS OF OWNERSHIP, ACCESS AND TRADE IN DIGITAL DATA. 2017. 6-8.o., 38-40.o.

${ }^{46}$ Helberger ET AL. 2017. 1456-1459.o.

47 ARticle 29 Working Party, Guidelines on Automated INDIVIDUAL DECisionMAKING AND PROFILING FOR THE PURPOSES OF REGULATION 2016/679, 2017. 8.o. 
pedig kifejezetten megnőtt a profilalkotáson keresztüli adatgyűjtés és a fogyasztók ügyleti döntéseinek befolyásolása az üzleti szférában. ${ }^{48}$

$\mathrm{Az}$ adatkezelésen keresztül megvalósuló információs aszimmetria mintegy garanciális jellegű csökkentését hivatottak biztosítani az adatkezelési jogalapok $^{49}$ és az adatvédelmi alapelvek, amelyek értelemszerűen a fenti tevékenységek során is alkalmazandóak. A GDPR szerint az adatkezelést jogszerűen és tisztességesen, valamint az érintett számára átlátható módon kell végezni. A személyes adatok gyüjtése csak meghatározott, egyértelmű és jogszerű célból történhet. Az adatkezelés nem folytatható az ilyen célokkal össze nem egyeztethető módon, annak a szükségesre kell koncentrálódnia, céljának pedig megfelelőnek és relevánsnak kell lennie. A személyes adatoknak pontosnak és naprakésznek kell lenniük, tárolásuknak pedig olyan formában kell történnie, amely az érintettek azonosítását csak a szükséges ideig teszi lehetôvé. A személyes adatok kezelése során pedig az adatbiztonságra is figyelemmel kell lenni. ${ }^{50} \mathrm{Az}$ adattakarékosság alapelvét segítő, angol nyelven, „privacy by design and default’ elv alapján az adatkezelő az adatkezelés módjának meghatározásakor és az adatkezelés során olyan technikai és szervezési intézkedéseket hajt végre, amelyek célja az adatvédelmi elvek, valamint a GDPR követelményeinek teljesítéséhez és az érintettek jogainak védelméhez szükséges garanciák beépítése az adatkezelés folyamatába. Emellett, az adatkezelő biztosítja azt is, hogy alapértelmezés szerint csak olyan személyes adatok kezelésére kerüljön sor, amelyek a meghatározott adatkezelési cél szempontjából szükségesek. Ezen elv gyakorlati alkalmazására kerülhet sor a személyes adatok álnevesítésével is. ${ }^{51}$

Mindezek mellett, az adatvédelem céljainak teljesüléséhez a GDPR széleskörű jogosítványokat biztosít a felhasználók részére az érintetti

48 Article 29 Working Party, Guidelines on AUtOMATED INDIVIDUAL DECISIONMAKING AND PROFILING FOR THE PURPOSES OF REgUlation 2016/679, 2018. 11. Vö. SZŐKE, 2015. 63.; OECD, 2013. 61.o.

49 ARTIClE 29 WORKING PARTY OPINION 06/2014 ON THE NOTION OF LEGITIMATE INTERESTS OF THE DATA CONTROLLER UNDER ARTICLE 7 OF DIRECTIVE 95/46/EC, 2014. 16-23.o.

50 ARTICle 29 Working PARTY, 3/2013 OPINION ON PURPOSE LIMITATION, 2013. 4-36.; HELBERGER ET AL. 2017. 1432-1434.o.

51 EDPB Guidelines 4/2019 on Article 25 Data Protection by Design AND By Default, 2019. 6-23. o. 
jogokon keresztül, ${ }^{52}$ valamint védi a személyes adatokat az adatbiztonsági szabályokkal. ${ }^{53}$

Figyelemmel a fentiekre, megállapítható, hogy a GDPR szabályainak teljeskörú érvényesülése megfelelő védelmet biztosíthat a személyes adatoknak; de önmagában ez a védelem nem feltétlenül elegendő.

Konkrét példával megvilágítva: az olyan online platformok adatkezelése is, mint a Google, az Amazon, a Facebook vagy az Apple (GAFA) a fentiek szerint a GDPR hatálya alá tartozhat, azok kifejezett üzleti tevékenységére a GDPR szabályai azonban értelemszerūen nem alkalmazhatóak. ${ }^{54}$ Ebben az esetben sokkal inkább versenyjogi, fogyasztóvédelmi, illetve pénzügyi jogi kérdésekről van szó. Ahogyan arra több szerző is rámutat, a személyes adatok fizetőeszközkénti alkalmazása nemcsak adatvédelmi szempontból releváns, hanem a fogyasztókkal szembeni tisztességtelen kereskedelmi gyakorlat, valamint a tisztességtelen piaci magatartás keretein belül is értelmezhető. ${ }^{55}$

Mindezekre tekintettel, a fentiekben megfogalmazott hipotézissel összefüggésben talán nem túlzó azt állítani, hogy a jövő jogalkotásának meghatározó kérdése lehet további szabályok kidolgozása az adatvédelem területén, vagy akár a személyes adat adatvédelem, fogyasztóvédelem, versenyjog és pénzügyi jog metszetében történő elhelyezése. ${ }^{56}$

\section{KONKLÚZIÓ}

Az adatvédelmi szabályozás egyes korszakaiban a személyes adatok eltérő szerepet töltöttek be. Amíg az első generációs adatvédelmi törvények esetében az adatalany személyes adatai feletti rendelkezési jog kevésbé volt domináns, addig a második generációs szabályok már meghatározott jogokat biztosítottak az adatalanyoknak. A harmadik generációs szabályok leginkább a technológiára reflektáló adatvédelmi szabályokat jelentették. Az uniós jogban mindig is fontos szerep jutott az alapjogok biztosításának és a szabad adatáramlásnak.

\footnotetext{
52 Voss, 2016-2017. 225-226.o.

53 2016/679 (EU) rendelet 32-34. cikk

${ }^{54}$ EDPB GUIDELINES 3/2018 ON THE TERRITORIAL SCOPE OF THE GDPR (ARTICLE 3), 2019. 13-22.; C-40/17. SZ. ÜGY, 75-85.o.; Vö. ADA, 2013. 14-19.o.

55 HelBerger ET AL. 2017. 1428-1431.; Vö. MARTENS, 2016. 36-37.; CSONKA, 2018. 7-11.

56 Szükséges utalni arra, hogy az EU az adatgazdaság kiépítésével kapcsolatban folyamatosan tesz előrelépéseket. Vö. EUROPEAN STRATEGY FOR DATA, 2020. 2-34.
} 
A digitális egységes piaci stratégiával az uniós adatvédelem új korszakhoz érkezett. Az digitális és adatgazdaság kiépítése az adatok, köztük a személyes adatok gazdasági erejére összpontosít. A koncepciónak megfelelő szabályozás, a GDPR utat enged a személyes adatok üzleti felhasználásához, ugyanakkor megfelelő garanciákat is állít a személyes adatok védelméhez.

A technológiai innováció hatására azonban fennáll a lehetősége annak, hogy a személyes adat mint a teljes digitális gazdaság sui generis valutája jelenjen meg, amely helyzetet azonban a hatályos adatvédelmi szabályozás nem feltétlenül tud lekövetni.

Szükséges utalni arra is, hogy a személyes adatok kezelése az adatgazdaságban, a jelen és a jövő Big Data rendszereiben is aggályokat vethet fel. Habár a Big Data alkalmazható nem személyes adatokkal összefüggésben is (járványok terjedésének előrejelzése, gyógyszerek mellékhatásainak feltérképezése, etc.), az ilyen rendszerekben személyes adatok kezelése is megvalósulhat. ${ }^{57}$ Ahogyan azt az európai adatvédelmi biztos is hangsúlyozza, a Big Data rendszerekben a személyes adat mint sajátos „valuta” is megjelenik. ${ }^{58}$

Az innováció - legyen az akár technológiai, akár üzleti - kettősséget teremt. Egyrészről az online platformok vezető szerepet játszanak a gazdasági fejlődés jövőjét alátámasztó digitális értékek létrehozásában és a digitális egységes piac eredményes működése szempontjából kiemelten fontosak,${ }^{59}$ másrészről viszont aggályként fogalmazható meg velük szemben a személyes adatok üzleti felhasználása, a fogyasztói ügyleti döntések tisztességtelen befolyásolása, a magánszféra sérelme. ${ }^{60}$

Az uniós adatgazdaság kiépítésével ezek az aggályok vélhetően dominánssá válnak majd. Ennek okán a szerző valószínűsíti az uniós centralizált adatvédelmi szabályozás jövőbeli változását oly módon, hogy abban a személyes adatok védelmét több jogterület szabályai egészítik ki.

\section{FELHASZNÁLT IRODALOM}

Ardolino, M., Saccani, N., Arodegari, F., Perona, M. (2020): A Business Model Framework to Characterize Digital Multisided

\footnotetext{
${ }^{57}$ Big Data Nyilatkozat, 2014. 1.

58 Az európai adatvédelmi biztos előzetes véleménye, 2014. 8.

${ }^{59}$ Európai Bizottság Online platform közlemény, 2016. 2-3.

${ }^{60}$ Vö. Helberger et al. 2017. 1429.
} 
Platforms, Journal of Open Innovation: Technology, Market and Complexity, 2020, Vol.6, Nr.10 (Letöltve: 2020. 04. 27.) DOI azonosító: https://doi.org/10.3390/joitmc6010010

ARTICle 29 WORKING PARTY WORK PROGRAMME 2014-2015. (2013) 1-3. Elérhető: $\quad$ https://ec.europa.eu/justice/article29/documentation/opinion-recommendation/files/2013/wp210 en.pdf (Letöltve: 2020. 04. 28.)

ARTIClE 29 Working PARTY OPINION 4/2007 ON THE CONCEPT OF PERSONAL DATA (2007) 12-21.

Elérhető:

https://ec.europa.eu/justice/article-29/documentation/opinionrecommendation/files/2007/wp136 en.pdf (Letöltve: 2020. 04. 30.) ARTICLE 29 WORKING PARTY OPINION 2/2010 ON ONLINE BEHAVIOURAL ADVERTISING (2010), 4-5. Elérhető: https://ec.europa.eu/justice/article29/documentation/opinion-recommendation/files/2010/wp171_en.pdf (Letöltve: 2020. 04. 30.)

ARTICle 29 Working PARTY 3/2013 OPINION ON PURPOSE LIMITATION (2013) 4-36. Elérhető: https://ec.europa.eu/justice/article29/documentation/opinion-recommendation/files/2013/wp203 en.pdf (Letöltve: 2020. 04. 30.)

ARTICle 29 Working PARTY, GUIDELINES ON AUtOMATED INDIVIDUAL DECISION-MAKING AND PROFILING FOR THE PURPOSES OF REGULATION 2016/679 (2017) 8. Elérhetô: https://ec.europa.eu/newsroom/article29/document.cfm?action=displa y\&doc id=49826 (Letöltve: 2020. 04. 28.)

AZ EURÓPAI ADATVÉDELMI BIZTOS ELŐZETES VÉLEMÉNYE (2014) 8.

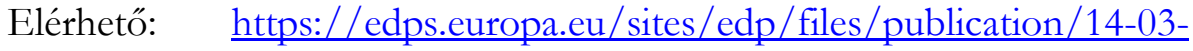
26 competitition law big data ex sum hu 0.pdf (Letöltve: 2020. 04. 27.)

Az Európai Parlament És a TANÁcs 2016. ÁPrilis 27-I (EU) 2016/679 RENDELETE A TERMÉSZETES SZEMÉLYEKNEK A SZEMÉLYES ADATOK KEZELÉSE TEKINTETÉBEN TÖRTÉNŐ VÉDELMÉRŐL ÉS AZ ILYEN ADATOK SZABAD ÁRAMLÁSÁRÓL, VALAMINT A 95/46/EK RENDELET HATÁLYON KÍVÜL HELYEZÉSÉRŐL

AdA, SERKAn (2013): Two-Sided Markets: Apples Digital Application Platform, Journal of Social Sciences, Vol. 1. No.1. Elérhető: https://tinyurl.com/y776kuov (Letöltve: 2020. 04. 08.) DOI azonosító: https://doi.org/10.24297/jssr.v1i1.3053 
A BizotTság KÖZleménye aZ Európai ParlamentneK, a TANÁCSNAK,

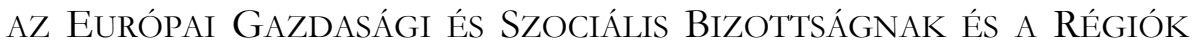
BiZOTTSÁGÁNAK, EURÓPAI DIGITÁLIS EGYSÉGES PIACI STRATÉGIA (2015), Európai Bizottság, 2-3., 9-17. Elérhető: https://eurlex.europa.eu/legal-content/HU/TXT/?uri=celex\%3A52015DC0192 (Letöltve: 2020. 04. 08.)

A BizotTsÁg KÖZLEMÉNYE AZ EURÓPAi PARLAMENTNEK, A TANÁCSNAK, AZ EuRÓpai GaZdasÁgI ÉS SZOCIÁlis BizOTTSÁGNAK ÉS A RÉGIÓK BIZOTTSÁGÁNAK, ÚTON A PROSPERÁLÓ ADATKÖZPONTÚ GAZDASÁG FELÉ (2014), Európai Bizottság, 4-6., 12. Elérhető: https://eurlex.europa.eu/legal-content/HU/TXT/?uri=celex:52014DC0442 Letöltve: 2020. 04. 08.)

BENDIK TAMÁs (2018): A tagállami jog és a GDPR viszonya - az Infotv. szerepe a megváltozott szabályozási környezetben. In: Péterfalvi Attila Révész Balázs - Buzás Péter szerk.: Magyarázat a GDPR-ról. Budapest, Wolters Kluwer Hungary.

Bergemann Dirk - Bonatti, Alessandro (2015): Selling Cookies, American Economic Journal: Microeconomics, Vol.7. Nr.3. (Letöltve: 2020. 04. 28.) DOI azonosító: $10.1257 /$ mic. 20140155

Big Data Nyilatkozat (2014), Adatvédelmi Biztosok 36. Nemzetközi Konferenciája, 1. Elérhető: https://www.naih.hu/files/Nyilatkozat-BigData.pdf (Letöltve: 2020. 04. 30.)

BuzÁs PÉTER (2018): Az érintett jogai. In: Péterfalvi Attila - Révész Balázs - Buzás Péter szerk.: Magyarázat a GDPR-ról. Budapest, Wolters Kluwer Hungary.

C-40/17. SZ. ÜGY FASHION ID GMBH \& CO. KG KONTRA VERBRAUCHERZENTRALE NRW EV [ECLI:EU:C:2019:629] 75-85. pont

C-582/14. SZ. ÜGY PATRICK BREYER KONTRA BUNDESREPUBLIK DEUTSCHLAND [ECLI:EU:C:2016:779] 39-39. pontok

C-673/17. SZ. ÜGY BUNDESVERBAND DER VERBRAUCHERZENTRALEN UND VERBRAUCHERVERBÄNDE - VERBRAUCHERZENTRALE BUNDESVERBAND E.V. KONTRA PLANET49 GMBH [ECLI:EU:C:2019:801] 76-81. pontok

C-212/13. SZ. ÜGY FRANTIŠEK RYNEŠ KONTRA ÚŘAD PRO OCHRANU OSOBNÍCH ÚDAJŮ [ECLI:EU:C:2014:2428] 31. pont

C-101/01. SZ. ÜGY BODIL LINDQVIST ELLENI BÜNTETŐELJÁRÁS [ECLI:EU:C:2003:596] 99. pont

COMMUNICATION FROM THE COMMISSION TO THE EUROPEAN PARLIAMENT, THE COUNCIL, THE EUROPEAN ECONOMIC AND SOCIAL 
Committee And the Committee of the Regions: Building A EUROPEAN DATA ECONOMY (2017), 5. Elérhetô: https://ec.europa.eu/digital-single-market/en/news/communicationbuilding-european-data-economy (Letöltve: 2020. 04. 29.)

COMMISSION STAFF WORKING DOCUMENT ON THE FREE FLOW OF DATA AND EMERGING ISSUES OF THE EUROPEAN DATA ECONOMY (2017), 4. Elérhetô: $\quad$ https://ec.europa.eu/digital-single-market/en/news/staffworking-document-free-flow-data-and-emerging-issues-european-dataeconomy (Letöltve: 2020. 04. 29.)

CsONKA Vivien (2018): Az európai adatgazdaság és a Big Data Elérhető: http://www.mie.org.hu/2018 osz/MIE csonka.pdf (Letöltve: 2020. 04. 30.)

EDPB Guidelines 4/2019 on ARTICle 25 Data Protection by DESIGN AND BY DEFAULT (2019) 6-23. Elérhető: https://edpb.europa.eu/sites/edpb/files/consultation/edpb guidelines 201904 dataprotection by design and by default.pdf (Letöltve: 2020. 04. 29.)

EDPB GUIDELINES 3/2018 ON THE TERRITORIAL SCOPE OF THE GDPR (ARTICLE 3) (2019) 5-28. Elérhetô: https://edpb.europa.eu/sites/edpb/files/files/file1/edpb guidelines 3 2018 territorial scope after public consultation en 1.pdf (Letöltve: 2020. 04. 29.)

EDPS RESPONSE ON THE REGULATORY ENVIRONMENT FOR PLATFORMS, ONLINE INTERMEDIARIES, DATA AND CLOUD COMPUTING AND THE COLLABORATIVE ECONOMY (2015). Elérhető: https://edps.europa.eu/sites/edp/files/publication/15-1216 online platforms en.pdf (Letöltve: 2020. 04. 29.)

ENISA (2012): Study on monetising privacy. An economic model for pricing personal information, Brussels: ENISA

ESZTERI DÁNIEL (2018): A GDPR tárgya és hatálya. In: Péterfalvi Attila Révész Balázs - Buzás Péter (2018): Magyarázat a GDPR-ról. Budapest, Wolters Kluwer Hungary.

EURÓPAi BIZOTTSÁG ONLINE PLATFORM KÖZLEMÉNY (2016). Elérhető: https:// eur-lex.europa.eu/legal-

content/HU/TXT/HTML/?uri=CELEX:52016DC0288\&from=EN

(Letöltve: 2020. 04. 27.)

Európai TANÁcS 2013. OKTÓBER 24-25. KÖVETKEZTETÉSEK (2013) 4. Elérhetô: 
https://register.consilium.europa.eu/doc/srv?l=HU\&f $=$ ST $\% 20169 \% 20$ 2013\%20INIT (Letöltve: 2020. 04. 29.)

EURÓPAI BIZOTTSÁG ONLINE PLATFORM KÖZLEMÉNY (2016), 2-3. Elérhetô: https://eur-lex.europa.eu/legalcontent/HU/TXT/HTML/?uri=CELEX:52016DC0288\&from=EN Letöltve: 2020. 04. 28.

EU COMMISSION A NEW ERA FOR DATA PROTECTION IN THE EU (2018), 1 3. Elérhető: https://ec.europa.eu/info/sites/info/files/data-protectionfactsheet-changes en.pdf (Letöltve): 2020. 04. 30.)

EU SZAKPOLITIKÁK, ADATVÉDELMIM REFORM (2020). Elérhetô: https://www.consilium.europa.eu/hu/policies/data-protection-reform/ (2020. 04. 28.)

European Commission: JRC Digital ECONOMy Working PAPER: THe ECONOMICS OF OWNERSHIP, ACCESS AND TRADE IN DIGITAL DATA (2017).

Elérhetô: https://ec.europa.eu/jrc/sites/jrcsh/files/jrc104756.pdf (Letöltve: 2020. 04. 27.)

EPRS (2020), European Parliament, 3-4. Elérhető: https://tinyurl.com/ydhjrp31 (Letöltve: 2020. 04. 09.)

EUROPEAN COMMISSION (2020) European Strategy for Data, 1-34. Elérhetô: $\quad$ https://ec.europa.eu/info/sites/info/files/communicationeuropean-strategy-data-19feb2020 en.pdf (Letöltve: 2020. 04. 30.)

FURMAN JELENTÉS (2019), 21-24. Elérhető: https://assets.publishing.service.gov.uk/government/uploads/system/u ploads/attachment data/file/785547/unlocking digital competition fu rman review web.pdf (Letöltve: 2020. 04. 30.)

GrAEF, I. (2015): Market definition and market power in data: The case of online platforms. World Competition Law and Economics Review, Vol.38 Nr.4. (Letöltve: 2020. 04. 27.) DOI azonosító: http://dx.doi.org/10.2139/ssrn.2657732

HelBerger, N. - ZuiderVeen, B. - ReYNA, A. (2017): The perfect match? A closer look at the relationship between EU consumer law and data protection law, Common Market Law Review, Vol. 54. Nr. 5. (Letöltve: 2020. 04. 30.)

JÓRI ANDRÁS (2018): A személyes adat. In: Jóri András - Soós Andrea Klára - Bártfai Zsolt - Hári Anita: A GDPR magyarázata. Budapest, HVG Orac Lap- és Könyvkiadó Kft. 
JÓRI ANDRÁs (2018): Az adatvédelem alapelvei. In: Jóri András - Soós Andrea Klára - Bártfai Zsolt - Hári Anita: A GDPR magyarázata. Budapest, HVG Orac Lap- és Könyvkiadó Kft.

JÓRI ANDRÁS - SOÓs ANDREA KLÁRA (2016): Adatvédelmi jog, Magyar és európai szabályozás, Budapest, HVG Orac Lap- és Könyvkiadó Kft.

Kerber, Wolfgang (2016): Digital markets, data, and privacy: Competitionlaw, consumer law, and data protection, MAGKS Joint Discussion Paper Series in Economics, No. 14-2016, Elérhető: https://www.econstor.eu/bitstream/10419/144679/1/850599016.pdf (Letöltve: 2020. 04. 29.)

LUKÁCS ADRIENN (2017): Adatvédelmi irányelv és rendelet, avagy hogyan változott a közösségi oldalakra vonatkozó szabályozás az Európai Unió adatvédelmi reformjával? In: Homoki-Nagy Mária - Hajdú József szerk.: Ünnepi kötet dr. Zakar András c. egyetemi tanár 70. születésnapjára. Szeged, Acta Universitatis Szegediensis. Acta Juridica et Politica.

MAJTÉNYI LÁSZLÓ (2003): Az információs jogok. In: Halmai Gábor - Tóth Gábor Attila szerk.: Emberi jogok. Budapest, Osiris.

Martens, Bertin (2016): An Economic Policy Perspective on Online Platforms JRC Technical Report 2016/05. 13-14. Elérhető: https://ec.europa.eu/jrc/sites/jrcsh/files/JRC101501.pdf (Letöltve: 2020. 04. 29.)

MAYER-SCHÖNBERGER, VIKTOR (1997): Generational Development of Data Protection in Europe. In: Agre, Philip E. - Rotenberg, Marc ed.: Technology and Privacy: The New Landscape. Cambridge, The MIT Press.

OECD (2013): Exploring the Economics of Personal Data, A Survey of Methodologies for Measuring Monetary Value, 7-9. Elérhető: https://www.oecd-ilibrary.org/docserver/5k486qtxldmqen.pdf?expires $=1588097065 \& \mathrm{id}=\mathrm{id} \&$ accname $=$ guest $\&$ checksum $=31 \mathrm{BC}$ C31C31A06347D1F25F6FC0C252F7 (Letöltve: 2020. 04. 29.)

OECD (2015): Data-driven innovation: Big data for growth and well-being, OECD, Paris.

OsZTopÁNi KRISZTiÁN - RÉvÉSz BALÁzs (2018): Alapfogalmak. In: Péterfalvi Attila - Révész Balázs - Buzás Péter (2018): Magyarázat a GDPR-ról. Budapest, Wolters Kluwer Hungary.

SZABÓ ENDRE GYŐZŐ (2017): A kétoldalú piacok elmélete és a személyes adatok védelme - a Google-ítélet elemzése versenyjogi és adatvédelmi 
szempontok szerint. In Media Res, Vol.6. No. 1. Elérhető: https://tinyurl.com/yaf2svkj (Letöltve: 2020. 04. 08.)

SZŐKE GERGELY LÁSZLÓ (2014): Az Európai adatvédelmi jog megújítása, Tendenciák és lehetôségek az önszabályozás területén, Budapest, HVG Orac Lap- és Könyvkiadó Kft.

Szűcs Gáborné (2020): Az online kereskedelem térhódítása és szabályozása, Külügyi Mûhely, 2020/1. szám. Elérhetô: DOI azonosító: https://doi.org/10.36817/km.2020.1.4

TNS-NIPO (2011): Attitudes on Data Protection and Electronic Identity in the European Union. In: Eurobarometer 359. Brussels: European Commission (2011) Elérhető: https://ec.europa.eu/commfrontoffice/publicopinion/archives/ebs/ebs 359 en.pdf (Letöltve: 2020. 04. 29.)

Voss, W. Gregor (2017): European Union Data Privacy Law Reform: General Data Protection Regulation, Privacy Shield, and the Right to Delisting, The Business Lawyer; Vol. 72, Winter 2016-2017 (Letöltve: 2020. 04. 28.)

ZARSKY, TAL Z. (2017): Incompatible: The GDPR in the Age of Big Data, Seton Hall Law Review, Vol. 47, No. 4(2) Elérhető: https://ssrn.com/abstract $=3022646$ (Letöltve: 2020 . 04. 30.) 